\title{
ANALISIS KESALAHAN BAHASA PADA TEKS CERAMAH SISWA SEKOLAH MENENGAH KEJURUAN
}

\author{
Arinta Ayu Stevania, Nugraheni Eko Wardani, Andayani \\ Universitas Sebelas Maret \\ Email: stevaniaarinta@gmail.com
}

\begin{abstract}
Abstrak: Penelitian ini bertujuan untuk mendeskripsikan: (1) ragam kesalahan berbahasa Indonesia dalam teks ceramah siswa, (2) faktor penyebab terjadinya kesalahan berbahasa Indonesia dalam teks ceramah, dan (3) upaya yang dapat dilakukan untuk mengatasi kesalahan berbahasa Indonesia dalam teks ceramah siswa kelas XI SMK Murni 1 Surakarta tahun ajaran 2018/2019. Jenis penelitian ini adalah penelitian kualitatif. Teknik pengambilan sampel dengan purposive sampling dan in-dept interview. Peneliti menggunakan teknik analisis interaktif, dengan sumber data utama teks ceramah siswa kelas XI SMK Murni 1 Surakarta. Digunakan teknik triangulasi teori sebagai uji validitas data. Hasil analisis temuan mengenai kesalahan berbahasa pada teks ceramah dibedakan dengan taksonomi linguistik dapat dijelaskan sebagai berikut. Pertama, kesalahan berbahasa yang ditemukan dalam teks ceramah siswa dapat dibagi menjadi empat, yaitu kesalahan morfologi sebesar 4,58\%, semantik sebesar 5,15\%, sintaksis sebesar 6,10\% dan ejaan sebesar $84,35 \%$. Kedua, kesalahan berbahasa siswa disebabkan oleh beberapa faktor, diantaranya: (a) kekurang pahaman dan ketidak telitian siswa dalam menulis suatu teks, (b) terbatasnya sumber belajar siswa, dan (c) kurangnya kepekaan siswa terhadap perkembangan bahasa. Ketiga, upaya untuk meminimalisir kesalahan berbahasa yang dapat dilakukan, diantaranya: (a) evaluasi hasil tulisan siswa, (b) menambah sumber belajar, dan (c) literasi dan latihan menulis untuk siswa.
\end{abstract}

Kata kunci: kesalahan berbahasa Indonesia, teks ceramah, taksonomi linguistik.

\section{LANGUAGE ERRORS ANALYSIS ON STUDENTS' DISCOURSE TEXT IN VOCATIONAL HIGH SCHOOL}

\begin{abstract}
This research aims to describe: (1) a variety of a language error in Indonesia text lectures students (2) the factors cause the occurrence of an error in the text of the lecture, and (3) efforts that can be made to address errors in the text of the lecture Indonesia students of class XI SMK Murni 1 Surakarta 2018/2019 school year. This type of research is qualitative research. The technique of sampling with purposive sampling and in-dept interview Researchers using interactive analysis techniques, with the primary data source text lectures students of class XI SMK Murni 1. Theory triangulation technique is used as a test of the validity of the data. The results of the analysis of the findings of language errors in the text of the lecture differentiated by linguistic taxonomy can be explained as follows. First, the language errors are found in the text of the lecture students of class XI can be divided into four, namely the fault of $4.58 \%$ morphology, $5.15 \%$ of semantics, $6.10 \%$ of syntax and spelling of $84.35 \%$. Second, the error-speaking students due to several factors, including: (a) unfamiliarity and lack of carelessness students in writing a text, $(b)$ the limited sources of student learning, and (c) the lack of sensitivity of the student on the development of the language. Third, efforts to minimize the mistakes that language can do, including: (a) assessment of the student's writing, (b) add the learning resources, and (c) literacy and writing exercise for students.
\end{abstract}

Keywords: Indonesia-language errors, text lectures, linguistic taxonomy.

BASASTRA Jurnal Bahasa, Sastra, dan Pengajarannya

Volume 8 Nomor 1, April 2020, P-ISSN 2302-6405, E-ISSN 2714-9765 


\section{PENDAHULUAN}

Pentingnya pembelajaran Indonesia sendiri, mengingat bahwa bahasa Indonesia berke-dudukan sebagai bahasa nasional yaitu bahasa pemersatu bangsa. Bahasa Indonesia sebagai cerminan identitas bangsa Indonesia. Sebagai bahasa Negara, bahasa Indonesia digunakan dalam hal-hal yang bersifat resmi misalnya dalam kegiatan pendidikan, pidato upacara, ceramah, peristiwa penting kene-garaan dan lain sebagainya. Oleh karena itu, mengetahui pentingnya kedudukan bahasa Indonesia sebagai bagian dari bangsa Indonesia, maka salah satu langkah yang dapat dilakukan adalah dengan menjaga bahasa Indonesia dengan menera-pkannya dalam dunia pendidikan.

Pembelajaran bahasa Indone-sia tidak dapat dijauhkan dengan keempat aspek keterampilan berba-hasa. Sayangnya, kurangnya penge-tahuan dan penguasaan siswa mengenai aspek-aspek keterampilan berbahasa membuat siswa kurang menguasai penggunaan bahasa Indonesia yang baik dan benar. Hal ini biasa disebut dengan kesalahan berbahasa. Upaya pemerintah men-standarkan ranah (domain) ejaan dan tata bahasa, agar memudahkan seluruh kalangan masyarakat, termasuk pelajar supaya dapat menggunakan bahasa Indonesia dengan baik dan benar melalui Pedoman Ejaan Bahasa Indonesia (PUEBI) nyatanya masih kurang diapresiasi. Kesalahan berbahasa dapat dikategorikan pada jalur bahasa lisan dan jalur bahasa tulis. Menurut Hastuti (2003: 83-84) bahasa lisan lebih memunyai kesan mudah dan berguna untuk komunikasi, bersifat longgar serta cenderung kurang mengikuti kaidah kebahasaan yang ada. Sedangkan bahasa tulis harus memperhatikan norma dan kaidah bahasa baku, bersifat terikat dengan tata bahasa serta pemilihan diksi sehingga pembaca tidak ragu dan dapat memahami isi serta menarik kesimpulan sesuai yang diharapkan oleh penulis. Bahasa tulis juga harus memperhatikan sistematika penyusunan kalimat serta ejaan.

Sejauh ini, pembelajaran tulismenulis atau mengarang di sekolah masih dinilai kurang berhasil. Pembelajaran menulis tidak diberikan secara detail dan efektif, sebagian besar hanya memberikan bimbingan sekedarnya kepada siswa. Tidak heran apabila siswa kurang memperhatikan masalah teknis dalam menulis, baik segi isi maupun bahasa yang digunakan sehingga memiliki pengaruh besar dalam kesalahan berbahasa. Menurut Setyawati (2010: 15-16) kesalahan berbahasa ketika menulis biasanya disebabkan karena pengaruh bahasa yang lebih dulu dikuasainya, kurang paham terhadap pemakaian bahasa, dan proses pem-belajaran bahasa yang tidak tepat. Setyawati melanjutkan ketika siswa melakukan kesalahan berbahasa, maka guru sebagai pengajar bahasa harus melakukan pengkajian secara mendalam segala aspek dan seluk beluk kesalahan tersebut. Hal ini dapat membantu mengurangi kesalahan berbahasa yang dilakukan oleh siswa sampai ke batas minimal. Walaupun secara umum, kesalahan berbahasa yang dilakukan oleh siswa, khususnya aspek menulis, merupakan hal wajar mengingat siswa masih dalam tahap belajar. Namun, apabila kesalahan tersebut dibiarkan terus-menerus tanpa adanya upaya perbaikan, akan menghambat ber-langsungnya pembelajaran.

Kenyataannya pembelajaran bahasa Indonesia masih belum dapat mencerminkan hal-hal yang diharap-kan. Seperti yang ditemui oleh peneliti saat melakukan Mangang Pendidikan III di SMK Murni 1 Surakarta. Berdasarkan hasil tulisan teks ceramah yang dibuat siswa pada saat pembelajaran bahasa, peneliti menemukan banyak kesalahan yang perlu dikaji lebih lanjut. Padahal seperti yang kita ketahui, dalam penulisan teks ceramah harus meng-gunakan bahasa formal dan baku. Tidak sedikit siswa melakukan kesa-

BASASTRA Jurnal Bahasa, Sastra, dan Pengajarannya

Volume 8 Nomor 1, April 2020, P-ISSN 2302-6405, E-ISSN 2714-9765 
lahan berbahasa yang sama, misalnya pada bidang ejaan, morfologi, sintak-sis, dan semantik.

Rumusan masalah pada penelitian ini adalah (1) bagaima-nakah ragam kesalahan berbahasa Indonesia dalam teks ceramah siswa kelas XI SMK Murni 1 Surakarta? (2) bagaimanakah faktor yang menye-babkan teradinya kesalahan berbahasa Indonesia dalam teks ceramah siswa? (3) bagaimana upaya yang dilakukan untuk mengatasi kesalahan berbahasa Indonesia dalam teks ceramah siswa?

\section{METODE PENELITIAN}

Jenis penelitian ini adalah penelitian kualitatif. Sumber data yang digunakan adalah peristiwa, dokumen, dan informan. Teknik pengambilan sampel dengan purpo-sive sampling untuk dokumen dan in-dept interview bersama guru bahasa Indonesia kelas XI SMK Murni 1 Surakarta. Peneliti menggunakan teknik analisis interaktif, dengan sum-ber data utama teks ceramah siswa kelas XI SMK Murni 1 Surakarta. Digunakan teknik triangulasi teori sebagai uji validitas data.

\section{HASIL DAN PEMBAHASAN \\ Ragam Kesalahan Berbahasa Indonesia dalam Teks Ceramah Siswa}

Kesalahan berbahasa Indo-nesia pada teks ceramah siswa dapat dilihat pada tabel berikut.

\begin{tabular}{|c|c|c|c|c|}
\hline No & Kategori Kesalahan & Jenis Kesalahan & $\begin{array}{c}\text { Jumlah } \\
\text { Kesalahan }\end{array}$ & $\begin{array}{c}\text { Jumlah } \\
\text { Total }\end{array}$ \\
\hline \multirow[t]{3}{*}{1.} & \multirow[t]{3}{*}{ Morfologi } & Penghilangan prefiks meng- & 20 & \multirow[t]{3}{*}{23} \\
\hline & & Bunyi yang tidak diluluhkan & 1 & \\
\hline & & Penggunaan afiks tidak tepat & 2 & \\
\hline \multirow[t]{8}{*}{2.} & \multirow[t]{8}{*}{ Sintaksis } & $\begin{array}{l}\text { Penggunaan unsur yang berlebihan atau } \\
\text { mubazir }\end{array}$ & 18 & \multirow[t]{8}{*}{32} \\
\hline & & Adanya pengaruh bahasa daerah & 4 & \\
\hline & & Penggunaan preposisi yang tidak tepat & 1 & \\
\hline & & Susunan kata yang tidak tepat & 1 & \\
\hline & & Bentuk superlatif yang berlebihan & 2 & \\
\hline & & Penjamakan ganda & 3 & \\
\hline & & Penghilangan kata penghubung & 1 & \\
\hline & & Penggunaan istilah asing & 2 & \\
\hline \multirow[t]{2}{*}{3.} & \multirow[t]{2}{*}{ Semantik } & Pemilihan kata yang tidak tepat & 22 & \multirow[t]{2}{*}{27} \\
\hline & & Pleonasme atau penggunaan unsur berlebihan & 5 & \\
\hline \multirow[t]{4}{*}{4.} & \multirow[t]{4}{*}{ Ejaan } & Kesalahan penulisan huruf & 194 & \multirow[t]{3}{*}{442} \\
\hline & & Kesalahan penulisan kata & 109 & \\
\hline & & Kesalahan penggunaan tanda baca & 139 & \\
\hline & & Jumlah Keseluruhan & & 524 \\
\hline
\end{tabular}

Selanjutnya peneliti akan sebagai upaya untuk mengatasi kesalahan menghitung presentase serta menguraikan berbahasa pada hasil tulisan siswa. setiap bentuk kesalahan untuk mengetahui Penghitungan pre-sentase kesalahan kesalahan berbahasa Indonesia yang paling berbahasa teks ceramah siswa dapat banyak muncul dalam teks ceramah siswa. dihitung dengan rumus berikut.

Hasil penghitungan ini dapat direfleksikan

$$
\begin{aligned}
& \text { Presentase Kesalahan }=\frac{\text { Jumlah kesalahan tiap jenis }}{\text { jumlah } \text { kesalahan total }} \times 100 \% \\
& \text { Dengan demikian, dapat dihitung } \quad \text { Presentase Sintaksis }=\frac{32}{524} \times \\
& \text { presentase kesalahan ber-bahasa Indonesia }
\end{aligned}
$$

Dengan demikian, dapat dihitung presentase kesalahan ber-bahasa Indonesia sebagai berikut.

$$
\begin{aligned}
& \text { Presentase Morfologi }=\frac{24}{524} \times \\
& 100 \%= \\
& 4,58 \%
\end{aligned}
$$$$
100 \%
$$$$
=6,10 \%
$$$$
\text { Presentase Semantik }=\frac{27}{524} \times
$$$$
100 \%
$$$$
=5,15 \%
$$

BASASTRA Jurnal Bahasa, Sastra, dan Pengajarannya 
Presentase Ejaan $=\frac{442}{524} \times 100 \%=$

$84,35 \%$

\section{Kesalahan Morfologi}

Diketahui kesalahan berbahasa tataran morfologi dalam teks ceramah siswa kelas XI SMK Murni 1 Surakarta adalah sebesar 4, 58\%. Jenis kesalahan mor-fologi terbanyak adalah peng-hilangan prefiks meng- yaitu sebanyak 25 kesalahan. Para siswa yang melakukan kesalahan jenis ini biasanya hanya membubuhkan sufiks -kan. Contoh kata yang paling banyak ditemui dalam teks ceramah siswa adalah 'panjatkan'. Kata tersebut ditemui dalam kalimat aktif transitif atau kalimat yang memiliki objek. Setyawati (2010: 50) menuliskan bahwa sesuai dengan kaidah kalimat aktif transitif predikat kalimat harus berprefiks mengatau dengan kata lain menge-plesitkan prefiks meng-, sehingga agar kalimat menjadi efektif kata 'panjatkan' dirubah menjadi 'memanjatkan'.

Kesalahan kedua ditemukan dalam teks ceramah siswa adalah peng-gunaan afiks tidak tepat. Contoh kata yang ditemukan dalam teks ceramah siswa 'di tertibkan' dan 'di laksanakan'. Pada kata 'di laksanakan' yang dima-ksudkan oleh siswa bukan kata depan di melainkan prefiks di-. Selain penu-lisannya salah, peng-gunaan prefiks $d i$ - pada kalimat tersebut kurang tepat, karena menyatakan suatu tindakan pasif. Kalimat tersebut akan sesuai kaidah bahasa Indone-sia apabila menggunakan prefiks men-.

Kesalahan yang tera-khir adalah bunyi yang tidak diluluhkan. Contoh kata yang ditemukan dalam teks ceramah siswa adalah 'mengkonsumsi'. Seperti yang kita ketahui sesuai kaidah penulisan, kata dasar berfo-nem awal $/ \mathrm{k} /, \quad / \mathrm{t} /, \quad / \mathrm{s} /$, dan $/ \mathrm{p} /$ seharusnya diluluhkan apabila mendapatkan prefiks meng-. Bunyi /k/, /t/, /s/ tidak luluh apabila kata tersebut merupakan serapan dari bahasa asing. Sedangkan konsumsi bukan merupakan kata sera-pan, sehingga huruf awal /k/ seharusnya luluh menjadi bunyi nasal atau bunyi sengau yaitu /k/ menjadi /ng/, sehingga kata yang benar adalah

Berdasarkan hasil analisis data, dapat disimpulkan bahwa sebagian besar siswa mampu cara pembentukan kata yang tepat. Jenis kesalahan morfologi di atas hampir sama dengan pe-nelitian Purwandari (2014), menurutnya kesalahan yang sering dilakukan oleh penulis adalah kesalahan afiksasi dan komposisi. Kesalahan terkait afiksasi dan penggunaan sufiks yang salah juga muncul dalam penelitian Usha (2016). Walaupun hanya sebagain kecil kesalahan morfologi yang ditemukan dalam satu wacana teks ceramah, akan tetapi tetap diperlukan tindak lanjut dari hasil temuan ini. Khusunya pada penghematan kata karena penghilangan prefiks meng-, penggunaan afiks yang tidak tepat dan bunyi yang seharusnya diluluhkan, agar siswa tidak melakukan kesalahan di tulisan lainnya.

\section{Kesalahan Sintaksis}

Diketahui kesalahan berbahasa tataran sintaksis dalam teks ceramah siswa kelas XI SMK Murni 1 Surakarta adalah sebesar $6,10 \%$. Kesalahan bidang sintaksis yang paling banyak ditemui dalam teks ceramah siswa adalah penggunaan unsur berlebihan yaitu sebanyak 18 bentuk. Siswa sering memakai kata-kata yang bermakna sama dalam sebuah kalimat tanpa disadari. Contohnya pada kalimat: Mohon maaf jika ada salah kata atau katakata yang kurang berkenan. Makna 'salah kata' dan 'kata-kata yang kurang berkenan' adalah sama, yaitu kata-kata yang tidak dapat diterima oleh pembaca atau pendengar. Apabila salah satu dihilangkan maka kalimat tersebut tetap bermakna meminta maaf kepada para pembaca atau pendengar. Penggunaan unsur berlebihan ini berdampak pada ketidak efektifan kali-mat.

Kesalahan selanjutnya disebabkan oleh pengaruh bahasa daerah yang menyebabkan kalimat menjadi tidak rancu. Ditemukan 4 kesalahan penulisan akibat pengatuh bahasa ibu. Contoh pada kalimat: Dimana kita dapat melakukan segala 
sesuatu yang negatif itu sangat didukung oleh lingkungan kita, teman-teman yang satu udah punya pacar satunya ikut-ikutan biar nggak dikatakan ketinggalan zaman. Kata 'udah', 'punya', 'satunya', 'ikutikutan', 'biar', dan 'nggak' merupakan bahasa Jawa yang biasa digunakan seharihari. Tanpa disadari pencampuran penggunaan bahasa ibu dalam percakapan atau tulisan bahasa Indonesia selama ini telah dianggap biasa. Masyarakat menganggap kalimat tersebut benar selama masih bisa dipahami.

Ditemukan tiga kesa-lahan jenis penjamakan ganda. Kesalahan ini hampir sama dengan penggunaan unsur yang mubazir, yaitu sama-sama membuat kalimat men-jadi tidak efektif. Kata yang banyak ditemui dalam teks ceramah siswa adalah kata 'para' yang diikuti bentuk jamak lainnya seperti kata 'bapak-bapak' atau 'hadirin sekalian'. Pengu-langan bentuk jamak ini membuat kalimat menjadi tidak efektif. Begitupula kesalahan bentuk superlatif berlebihan. Bentuk superlatif mengandung arti 'paling' dapat dihasilkan de-ngan suatu adjektiva ditambah adverbia amat, sangat, sekali, atau paling (Setyawati 2010: 81). Salah satu contoh penggalan kalimat yang ditemukan dalam teks siswa adalah: ... masih memberi kita banyak sekali nikmat-nikmat itu .... Kata 'banyak sekali' merupakan bentuk superlatif apabila ditambah kata 'nikmat-nikmat' yang ber-makna banyak nikmat, maka kalimat tersebut menjadi tidak efektif.

Sementara itu ditemu-kan juga penggunaan istilah asing yang digunakan oleh siswa dalam menulis teks ceramah. Contoh kata yang muncul diantaranya adalah 'fasion' dan 'boming'. Walau penulis sendiri salah dalam menulis kata asing yang seharusnya 'fashion' dan 'booming', maka lebih baik apabila kata tersebut diganti menjadi kata bahasa Indonesia sepeerti 'model pakaian' dan 'berkembang pesat'. Pencam-puran unsur bahasa asing dalam tulisan atau dalam percakapan dianggap lebih modern, padahal para siswa sendiri masih salah dalam menuliskannya. Penggunaan istilah asing tersebut menye-babkan kalimat menjadi rancu dan sulit untuk dipahami.

Kesalahan lain yang ditemukan dalam bidang sintaksis adalah kalimat tidak bersubjek dan penggunaan preposisi tidak tepat. Hal ini disebabkan siswa tidak mem-perhatikan susunan SPOK dalam kalimat. Siswa hanya menuliskan kalimat hanya sekedar dari temuan kosakata yang dirasa tepat tanpa memerhatikan dan memaknai pilihan kata dan diksinya. Hasil penemuan dalam pene-litian ini hampir sama dengan Lestari (2015) yang mengung-kapkan dalam penelitiannya, bahwa kesalahan sintaksis yang ditemukan dalam surat resmi berupa kesalahan penggunaan konjungsi berlebihan, penggunaan istilah asing, penghilangan konjungsi, preposisi yang tidak tepat dan susunan kata yang tidak tepat. Dapat disimpulkan bahwa siswa masih kurang paham dalam penyusunan kalimat. Siswa tidak dapat menentukan pilihan kata yang tepat untuk sebuah kalimat. Oleh karena itu, guru hendaknya lebih banyak mengulas tentang kalimat selama proses pem-belajaran, terutama penggu-naan unsur yang berlebihan sehingga kalimat menjadi efektif.

\section{Kesalahan Semantik}

Diketahui kesalahan berbahasa tataran semantik dalam teks ceramah siswa kelas XI SMK Murni 1 Surakarta adalah sebesar 5,15\%. Menurut Setyawati (2010: 103) kesalahan semantik ini penekanannya pada penyimpangan makna, baik yang berkaitan dengan fonologi, morfologi maupun sintaksis. Kesalahan semantik yang ditemukan dalam teks cera-mah siswa dalam penelitian ini digolongkan dalam dua jenis yaitu pemilihan kata yang tidak tepat dan pleonasme atau penggunaan unsur berlebihan.

Pemilihan kata yang tidak tepat berarti penggunaan kata yang maknanya tidak sesuai apabila digabung dalam sebuah kalimat. Contohnya pada kata 'fitrah' pada kalimat: Tanpa fitrah itu kita 
tidak dapat berkembangbiak sampai sekarang ini, mungkin kita tidak dapat berada disini. Pada kalimat tersebut ditemukan banyak kesalahan selain semantik yang tidak dibahas pada bagian ini. Kata 'fitrah' berasal dari bahasa Arab yang berarti membuka atau menguak, sedangkan dalam KBBI kata 'fitrah' berarti sifat asal; kesucian; bakat; dan pembawaan. Oleh karena itu, agar kalimat tidak menjadi rancu, akan lebih baik apabila kata 'fitrah' diganti menjadi 'anugerah'.

Pleonasme atau penggunaan unsur berlebihan merupakan salah satu faktor penyebab kalimat menjadi tidak efektif akan tetapi masih sering digunakan. Contohnya kata 'begitu' pada kalimat: Ada begitu banyak permasalahan yang terjadi di dunia remaja saat ini. Kata 'begitu' dalam KBBI memiliki makna sangat; terlalu. Padahal kalimat akan lebih efektif apabila menghilangkan kata 'begitu'.

Lestari (2015) dalam penelitiannya mengungkapkan kesalahan bidang semantik dalam surat resmi berupa kesalahan pemilihan kata dan kesalahan dalam penggunaan konjungsi. Sementara itu, Murtiningsih (2013) mengungkapkan kesalahan mahasiswa dalam penulisan kata rancu atau ambigu paling sedikit diantara kesalahgan yang lain yaitu sebesar $13,4 \%$. Kesalahan dalam bidang semantik teks ceramah siswa kelas XI SMK Murni 1 Surakarta tergolong sedikit. Walaupun begitu guru diharapkan tetap mengulas bagian pemilihan diksi, agar siswa dapat mengerti dan sebagai bekal dalam kegiatan menulis lainnya.

\section{Kesalahan Ejaan}

Diketaui kesalahan berbahasa tataran ejaan dalam teks ceramah siswa kelas XI SMK Murni 1 Surakarta adalah sebesar 84,35\%. Kesalahan ejaan pada tulisan siswa merupakan jenis kesalahan terbanyak. Jenis kesalahan ejaan terbanyak adalah kesalahan penulisan huruf yaitu sebanyak 192 kesalahan. Kesalahan ini berbentuk kesalahan pengunaan huruf kapital dan huruf bergaris bawah atau miring. Karena dalam penelitian ini siswa menulis teks ceramah dalam bentuk tulisan tangan bukan berupa teks yang diketik dengan komputer, maka hasilnya siswa lebih tidak memperhatikan tata penggunaan huruf. Huruf besar sering ditulis dalam pertengahan kalimat, huruf kecil digunakan pada awal kalimat, dan penggunaan bahasa arab atau istilah ilmiah yang tidak digaris bawah. Dimuat dalam Pedoman Umum Ejaan Bahasa Indonesia (PUEBI) bahwa huruf kapital diguna-kan sebagai huruf pertama awal kalimat, huruf pertama unsur nama orang atau julukan, dipakai pada awal kali-mat dalam petikan langsung, huruf pertama setiap unsur agama, huruf pertama unsur nama gelar kehormatan yang diikuti nama orang, huruf pertama nama gelar kehormatan yang dipakai sebagai sapaan, huruf pertama unsur nama ja-batan dan pangkat yang diikuti nama orang, dan lainnya.

Kesalahan yang sering dilakukan oleh siswa adalah kesalahan penulisan kata. Jenis kesalahan yang ditemukan dalam teks ceramah siswa adalah kesalahan penulisan bentuk ulang, kesalahan pemen-ggalan kata, kesalahan penulisan kata depan, kesalahan penulisan sing-katan, dan kesalahan dalam menulis angka serta bilangan. Kesalahan penulisan bentuk ulang biasanya siswa menulis dengan tanda pangkat dua $\left(^{2}\right)$ atau dengan tanda silang $\left({ }^{\times \times}\right)$. Kesalahan penulisan pemeng-galan kata yang paling banyak ditemukan berbentuk kata yang tidak cukup dalam satu baris akan langsung dilan-jutkan ke baris berikutnya tanpa membubuhkan tanda hubung (-) dan tanpa memperhatikan bentuk dasar kata tersebut. Temuan kesalahan penulisan kata depan terbanyak ialah ketika menulis kata depan di akan digabung dengan kata yang mengikuti. Kesalahan penu-lisan singkatan paling banyak ditemui karena pencampuran bahasa gaul, seperti menyingkat tulisan 'yang; menjadi 'yg', 'dapat' menjadi 'dpt', dan lain sebagainya.

Kesalahan pemakaian tanda baca merupakan kesalahan ejaan terbanyak nomor dua setelah kesalahan pemakaian 
huruf, yaitu sebesar 139 bentuk. Kesalahan yang sering ditemukan pada tulisan siswa adalah salah peletakan dalam membubuhkan tanda baca. Siswa membubuhkan spasi sebelum dan sesudah meletakkan tanda baca, padahal menurut aturan dalam PUEBI seharusnya tanda baca diletakkan mengikuti kata terakhir kemudian di beri spasi.

Berdasarkan analisis data, karena kesalahan ejaan adalah yang paling banyak ditemukan maka guru harus sering mengulas tentang ejaan. Hal ini dikarenakan sebagian besar siswa kurang mengetahui ketepatan peng-gunaan ejaan. Penulis berharap agar guru sering mengevaluasi hasil tulisan siswa agar sesuai dengan PUEBI, sehingga para siswa mampu terbiasa menulis dengan ejaan yang tepat.

Pemaparan hasil perhitungan presentase kesalahan berbahasa Indonesia pada teks ceramah siswa di atas, membuktikan bahwa kemampuan siswa dalam menulis masih rendah. Ditemukan kesalahan ejaan lebih dari $50 \%$ pada sampel data, hal ini menunjukkan penguasaan siswa dalam bidang ejaan sangat rendah. Kesalahan morfologi, semantik, dan sintaksis dalam tulisan siswa rendah, hal ini berarti siswa cukup mumpuni dalam hal pembentukan kata, menyu-sun sebuah kalimat, dan keterpaduan dalam makna sebuah kata atau kalimat.

Hal ini berkebalikan dengan penelitian Winata (2017) yang menyebutkan bahwa kesalahan penggunaan ejaan pada teks ceramah siswa kelas XI SMAN Banjar Margo lebih rendah, sedangkan ketepatan penggunaan ejaan lebih mendo-minasi. Akan tetapi, terdapat persamaan yaitu ketidaptepatan ejaan banyak ditemukan dalam penulisan huruf kapital, pada awal kalimat, serta nama atau ungkapan yang mengacu pada Tuhan.

\section{Penyebab Kesalahan Berbahasa Indonesia dalam Teks Ceramah \\ Faktor penyebab kesalahan} berbahasa pada siswa tentunya memiliki perbedaan setiap individu. Melalui hasil wawancara dengan guru kelas XI mata pelajaran bahasa Indonesia faktor penyebab siswa melakukan kesalahan berbahasa adalah para siswa yang kurang paham pemakaian ejaan dan tidak teliti. Menurut beliau, guru telah berusaha untuk menjelaskan tentang penulisan teks atau karangan dengan baik, dan akan diulangi apabila siswa belum mengerti. Hanya saja siswa biasanya menganggap remeh dan tidak me-meriksa hasil tulisannya ketika me-ngumpulkan. Hal ini sama dengan yang diungkapkan oleh Sermsook (2017) dalam penelitian analisis kesalahan berbahasa Inggris, bahwa kecerobohan siswa dapat menyebabkan kekeliruan dalam menulis.

Faktor kedua adalah terbatasnya sumber belajar. Melalui magang kependidikan 3, peneliti melakukan pengamatan di SMK Murni 1 Surakarta dan diizinkan untuk terlibat dalam proses belajar mengar kelas XI. Dari hasil pengamatan, satu-satunya sumber belajar siswa adalah guru. Terkadang, guru meminjamkan siswa LKS (Lembar Kerja Siswa) untuk mendukung proses pembelajaran. Tentunya hal ini masih tergolong kurang bagi siswa untuk mendapatkan sumber belajar. Belum tersedianya buku panduan dari pemerintah edisi revisi terbaru juga merupakan faktor penyebab siswa banyak melakukan kesalahan menulis (Ariningsih, Sumarwati, \& Saddhono, 2012). Penelitian yang dilakukan oleh Yerni (2014) juga menunjukkan terdapat hubungan yang signifikan antara ketersediaan sumber belajar dan kemampuan mahasiswa dalam menulis sebanyak $44 \%$. Sumber belajar dapat ditemukan tidak hanya melalui buku, misalnya bahan bacaan dari koran, majalah, novel dan lainnya telah banyak tersedia. 
Selain kedua faktor di atas, faktor terakhir adalah kurangnya kepekaan siswa dalam perkembangan bahasa Indonesia. Siswa kekurangan informasi apabila bahasa Indonesia yang dipakai sehari-hari hingga disepelekan mampu berkembang. Sifat tidak acuh terhadap perkembangan bahasa Indonesia menyebabkan banyaknya kesalahan berbahasa pada tulisan siswa. Siswa tidak tahu tulisan yang dibuatnya salah atau tidak, karena tidak mengetahui bahwa sudah ada pedoman yang mengatur tata kepenulisan terbaru. Menurut Setyawati (2010: 16) menyatakan salah satu faktor penyebab kesalahan ber-bahasa siswa Indonesia adalah kekurangpahaman pemakai bahasa terhadap bahasa yang dipakainya. Kesalahan itu berupa: (a) penyamarataan berlebihan, (b) ketidaktahuan pembatasan kaidah, (c) penerapan kaidah yang tidak sempurna, dan (d) salah menghipotesiskan konsep.

\section{Upaya Mengatasi Kesalahan Berbahasa Indonesia dalam Teks Ceramah}

Kesalahan berbahasa pada siswa memang harus segera di atasi, agar siswa mampu memperbaiki kesalahan pada tulisan-tulisan selanjutnya. Untuk itu peran guru sangatlah penting dalam proses perbaikan kesalahan, guru diharapkan terus membimbing siswa untuk mengurangi kesalahan yang ada. Setelah mengetahui faktor-faktor penyebab kesalahan pada teks ceramah siswa, maka tahap selanjutnya adalah mencari pemecahan masalah agar siswa mampu mengurangi kesalahan yang dibuatnya.

Langkah pertama yang dapat dilakukan oleh guru adalah mendiskusikan kesalahan berbahasa siswa dalam proses pembelajaran. Sermsook (2017) mengatakan meningkatkan kesadaran penulis tentang kerugian akibat kecerobohan dapat membantu mengurangi kesalahan berbahasa dalam tulisan mereka. Selama proses pengamatan, guru belum pernah melakukan evaluasi kembali terhadap kesalahan penulisan yang dilakukan oleh siswa. Hasil wawancara dengan siswa menun-jukkan bahwa, siswa sendiri tidak tahu tentang kesalahan yang dilaku-kan ketika menulis. Oleh sebab itu, sebaiknya guru lebih sering menga-dakan evaluasi terhadap tulisan siswa, sehingga siswa tidak mengulangi kesalahan yang dibuatnya.

Selanjutnya adalah penam-bahan sumber belajar. Sumber belajar dapat ditemukan tidak hanya melalui buku. Koran, majalah, novel, dan lainnya dapat digunakan sebagai sum-ber belajar. Selain itu, siswa dapat mencari referensi atau mengetahui tata cara penulisan yang benar dalam wacana yang terdapat sumber belajar tersebut, sehingga sumber belajar tidak hanya terfokus pada guru dan buku LKS saja. Penambahan PUEBI sebagai bahan ajar juga diperlukan, mengingat kesalahan yang palng banyak dilakukan oleh siswa adalah pada bidang ejaan serta ketidaktahuan siswa dalam penulisan kaidah kebahasaan yang benar. Purwandari (2014) menyatakan penyebab utama kesalahan berbahasa adalah kurang-nya penguasaan penulis terhadap kaidah bahasa Indonesia yang baik dan benar. Oleh karena itu, penam-bahan PUEBI sebagai bahan ajar atau pendukung dalam proses pembelajaran bahasa Indonesia sangat disarankan.

Dalam kurikulum 2013 revisi 2017 sudah terdapat penambahan literasi sebagai salah satu yang wajib dilakukan siswa. Pembelajaran literasi ini mampu meningkatkan kemampuan menulis siswa. Oleh karena itu, tambahan referensi dalam literasi sangat dianjurkan. Tidak hanya buku yang bersifat pengetahuan umum, tetapi kumpulan cerpen, novel, atau artikel-artikel ilmiah dapat membantu siswa mengetahui kaidah penulisan yang baik. Menulis rangkuman setelah melakukan literasi juga sangat dianjurkan, sehingga siswa menjadi terbiasa menulis. Latihan-latihan menulis teks juga diperlukan untuk mengasah kemahiran siswa. Yerni (2014) mengungkapkan bahwa terdapat hubungan signifikan antara intensitas latihan dan kemampuan 
mahasiswa dalam menulis sebanyak 53,9\%. Didukung dengan pernyataan Ariningsih, Sumarwati, dan Saddhono (2012) bahwa pembelajaran dan pelatihan meru-pakan dua kegiatan yang berkesinambungan yang terfokus pada aktivitas siswa mendapatkan suatu aktivitas tertentu dalam hal ini keterampilan menulis. Setelah latihan menulis dilakukan, diperlukan juga evaluasi kesalahan berbahasa dalam tulisan siswa, agar siswa mengetahui kesalahan apa saja yang telah dilakukannya.

\section{SIMPULAN}

Berdasarkan hasil analisis temuan dan pembahasan mengenai kesalahan berbahasa pada teks ceramah siswa kelas XI SMK Murni 1 Surakarta yang dibedakan dengan taksonomi linguistik dapat dijelaskan sebagai berikut. Pertama, kesalahan berbahasa yang ditemukan dalam teks ceramah siswa kelas XI dapat dibagi menjadi empat, yaitu kesalahan mor-fologi sebesar 4,58\%, semantik sebesar 5,15\%, sintaksis sebesar 6,10\% dan ejaan sebesar 84,35\%. Kedua, kesalahan berbahasa siswa kelas XI SMK Murni 1 Surakarta disebabkan oleh beberapa faktor, diantaranya: (a) kekurang pahaman dan ketidak telitian siswa dalam menulis suatu teks, (b) terbatasnya sumber belajar siswa, dan (c) kurangnya kepekaan siswa terhadap perkembangan bahasa. Dapat diketahui faktor yang paling memengaruhi kesalahan siswa adalah faktor internal dari siswa itu sendiri. Ketiga, upaya untuk meminimalisir kesalahan berbahasa yang dapat dilakukan, diantaranya: (a) evaluasi hasil tulisan siswa, (b) menambah sumber belajar, dan (c) literasi dan latihan menulis untuk siswa. Saran peneliti untuk siswa diantaranya dapat lebih fokus ketika guru sedang menjelaskan, tidak malu bertanya apabila mengalami kesulitan, memperluas informasi mengenai penggunaan tata bahasa dan pemakaian bahasa Indonesia. Bagi guru bahasa Indonesia, peneliti berharap guru melakukan evaluasi terhadap hasil tulisan siswa dan mendiskusikannya selama proses pembelajaran, guru bahasa Indonesia dapat secara aktif mengikuti berbagai kegiatan penyuluhan bahasa yang diadakan oleh Balai Bahasa Jawa Tengah. Saran untuk sekolah adalah melengkapi sumber belajar siswa dan sebaiknya pihak sekolah mendukung dan memberikan contoh kepada siswa mengenai tata bahasa yang baik dan benar.

\section{REFERENSI}

Ariningsih, N.E., Sumarwati, \& Saddhono, K. (2012). Analisis Kesalahan Berbahasa Indonesia dalam Karangan Eksposisis Siswa Sekolah Menengah Atas. BASASTRA Jurnal Penelitian Bahasa, Sastra Indonesia dan Pengajarannya 1(1), 4053.

Hastuti, S. (2003). Sekitar Analisis Kesalahan berbahasa Indonesia. Yogyakarta: PT Mitra Gama.

Lestari, N. H. Hadi, P. K., \& Meikayanti, E. A. (2015). Analisis Kesalahan Berbahsa dalam tataran Linguistik pada Surat-Surat Resmi di Kantor Desa Teguhan Kecamatan Paron Kabupaten Ngawi. Jurnal Widyabastra (3) 2, 66-75.

Murtiningsih. (2013). Kesalahan Berbahasa Indonesia Mahasiswa S1 PGSD STIKIP NUUWAR FAKFAK. Jurnal Penelitian Ilmu Pendidikan (6) 1, 74-82.

Purwandari, H. S., Setiawan, B., \& Saddhono, K. (2014). Analisis Kesalahan Berbahasa pada Surat Dinas Kantor Kepala Desa Jladri. BASASTRA Jurnal Bahasa, Sastra Indonesia dan Pengajarannya 1 (3), 478-489.

Setyawati, N. (2010). Analisis Kesalahan Berbahasa Indonesia Teori dan

Praktik. Surakarta: Yuma Pustaka. Sermsook, K., Liamnimitr, J., \& Pochakorn, R. (2017). An Analysis 
of Errors in Written English

Sentences: A Case Study of Thai EFL Students. English Language Teaching. 10 (3), 101-110.

Usha, P. \& Kader, N. A. (2016). Syntactic and Morphological Error Anaysis in English Language among Secondary School Students of Kerala. IOSR Journal Of Humanities and Socoal Science (21) 2, 99-103.

Winata, A.P. (2018). Pengunaan Bahasa pada Teks Ceramah Siswa Kelas XI SMAN Banjar Margo Tahun Ajaran 2017/2018. Skripsi. Bandar Lampung: Fakultas

Keguruan dan Ilmu Pendidikan, Universitas Lampung.

Yerni., Hasyim, A., \& Sudirman. (2014). Hubungan Minat Menulis, Intensitas Latihan, dan Ketersediaan Sumber Belajar dengan Kemampuan Menulis Teks Argumentatif Mahasiswa Program Pendidikan Bahasa Inggris STAIN Jurai Siwo Metro. Jurnal Teknologi Informasi Komunikasi Pendidikan, 2(3), 1-15. 